\title{
UTILIZAÇÃO DE BIOSPECKLE PARA ANÁLISE DAS PROPRIEDADES FÍSICAS E ÓPTICAS DA Moringa oleifera
} \author{
Resumo \\ Inácio Maria dal Fabbro (PQ), Gabriela Kurokawa e Silva (PG), Ivan Bazo Bergamim (IC). \\ Este projeto teve por intuito a análise das atividades biológicas e características físicas dos \\ materiais biológicos utilizando métodos "destrutivos". Além disso, objetivou-se fazer a comparação desses \\ resultados com análise "não destrutiva". Optou-se por fazer essa avaliação através da técnica óptica \\ Biospeckle, a qual mede a atividade biológica do material e a quantifica em um valor de Momento de Inércia \\ (MI). Como resultado, conseguiu-se estabelecer essa correlação para os parâmetros umidade.
}

Palavras Chave: Moringa oleifera, Biospeckle, Propriedades físicas e ópticas.

\section{Introdução}

O conhecimento das características físicas dos materiais biológicos é de grande importância para seu processamento, armazenamento e transporte. No entanto, algumas das análises que são realizadas inviabilizam o uso do material posteriormente. Uma das alternativas para não perder material e possibilitar o aumento do número de amostras analisadas são as técnicas ópticas de análise. Uma delas é a técnica de Biospeckle, a qual avalia a atividade biológica do material e a quantifica em um valor denominado Momento de Inércia (MI).

O objetivo desse trabalho foi correlacionar os parâmetros físicos umidade, cor, teor de gordura e teor de proteína com o parâmetro óptico MI. Para tal foram utilizadas as sementes de Moringa oleifera. Optou-se por esse produto pois ele é de grande importância para o tratamento alternativo de água visando pequenas comunidades.

\section{Resultados e Discussão}

Foram avaliadas sementes de moringa em 4 estádios diferentes de maturação: (A) vagens verdes com sementes verdes; $(B)$ vagens verdes com sementes marrons; $(C)$ vagens secas com sementes secas mas ainda fechadas na árvore; e (D) vagens secas com sementes secas mas já abrindo na árvore.

A Tabela 1 apresenta os resultados médios obtidos paraas análises de Umidade, Cor, Teor de Gordura, Teor de proteína e MI.
Tabela 1. Dados dos parâmetros analisados

\begin{tabular}{|c|c|c|c|c|c|c|c|}
\hline \multirow{2}{*}{$\begin{array}{c}\text { Umidade } \\
(\%)\end{array}$} & \multicolumn{4}{|c|}{ Cor (Espectrofotometria) } & \multirow{2}{*}{$\begin{array}{c}\text { Gordura } \\
(\%)\end{array}$} & \multirow{2}{*}{$\begin{array}{c}\text { Proteína } \\
(\%)\end{array}$} & \multirow{2}{*}{ MI } \\
\hline & $\mathrm{L}^{*}$ & $a^{*}$ & $\mathbf{b}^{*}$ & Croma & & & \\
\hline 70,2 & 80,0 & $\overline{1,1}$ & 30,8 & 30,8 & 33,0 & 11,0 & 7,4 \\
\hline 39,3 & 44,7 & 7,2 & 14,9 & 16,6 & 30,0 & 11,0 & 5,2 \\
\hline 16,2 & 42,6 & 6,2 & 13,3 & 14,7 & 31,0 & 10,0 & 4,0 \\
\hline 10,2 & 40,0 & 6,1 & 11,9 & 13,5 & 29,0 & 10,0 & 3,7 \\
\hline
\end{tabular}

Verificou-se que houve diferença entre os estádios de maturação para os parâmetros umidade, cor e MI. Para a cor, já era esperado que apenas 0 estádio $A$ apresentasse cor diferente dos outros, visto que apresentava as sementes verdes, enquanto as outras eram marrons. Já com relação à umidade e o MI, notase que há uma correlação entre seus valores, sendo que quanto mais alta a umidade, maior o valor do momento de inércia. Sendo assim, conclui-se que é possível um trabalho futuro que determine uma equação que determine indiretamente a umidade através do MI.

\section{Conclusões}

Através do trabalho apresentado, é possível se concluir que a umidade pode ser relacionada com a atividade biológica dos materiais biológicos, quantificado pelo Momento de Inércia. Já com relação aos outros parâmetros avaliados, não foi possível fazer essa correlação, pois não houve variação significativa entre os diferentes estádios de maturação das sementes.

\section{Agradecimentos}

- FAPESP (Número do processo: 2013/11652-9)

- Faculdade de Engenharia Agrícola da UNICAMP (FEAGRI) 